\title{
Viagem à Índia: Cecilia Meireles e Octavio Paz
}

\section{Luís Antônio Contatori Romano}

Professor de Estudos

Literários na Universidade Federal do Pará desde 2006

Pós-doutorando em Teoria Literária pelo IEB (Instituto de Estudos Brasileiros) da USP (Universidade de São Paulo), onde desenvolve o projeto “Uma Teoria Poética da Viagem e do Viajante Contemporâneo nas Crônicas de Cecília Meireles", financiado com bolsa PDS (Pós-Doutorado Sênior) pelo CNPq. É autor dos livros A Passagem de Sartre e Simone de Beauvoir pelo Brasil em 1960 (Campinas, Mercado de Letras-Fapesp, 2002) e Reminiscências de um Viajante (Campinas, Komedi, 2007).

Contato: luisr@ufpa.br 
CARACOL 3 / DOSSIÊ

Palavras-chave: Cecília

Meireles; Octavio Paz;

Literatura de Viagens.

KEYWords: Cecilia Meireles;

Octavio Paz; Travel Literature.
Resumo: A partir da abordagem interdisciplinar que caracteriza a Literatura de Viagens, este trabalho visa analisar crônicas de Cecília Meireles sobre sua estada na Índia, comparativamente a fragmentos de obra de Octavio Paz em que relata suas impressões desse país asiático. Propomos diálogo com o conceito de Literatura de Viagem apresentado por Fernando Cristóvão, com a abordagem de linguagem poética tal como discutida por Octavio Paz e com a Teoria das Reminiscências de Platão e suas ressonâncias em textos de viagem de Cecília Meireles.

ABSTRACT: Taking into consideration the interdisciplinary approach that characterizes Travel Literature, this text aims to analyze the chronicles Cecília Meireles wrote during her stay in India in comparison to fragments of Octavio Paz works in which he tells his impressions of that Asian country. Connection is established between the concept of Travel Literature presented by Fernando Cristóvão and Octavio Paz's approach to poetic language. Plato's Reminiscence Theory is also concerned due to its resonance for Cecília Meireles' texts. 
Viagem À Índia: Cecília Meireles e Octavio Paz

LuÍS ANTÔNIO CONTATORI ROMANO

Este TRABAlHo é PARTE de uma pesquisa de pós-doutorado, desenvolvida no Instituto de Estudos Brasileiros da USP, sobre as crônicas de viagem de Cecília Meireles, escritas essencialmente para a imprensa entre as décadas de I940 e I960, compiladas e organizadas em três tomos pelo Prof. Leodegário de Azevedo Filho, publicados entre 1998 e 1999 .

Nossa perspectiva de abordagem, no contexto da interdisciplinaridade própria da Literatura de Viagens, dialoga diretamente com a do crítico Fernando Cristóvão (2002), que considera que a Literatura de Viagens teve seu auge entre fins do século XV e meados do XIX, quando nada mais de novo havia para ser narrado pelos viajantes, pois os meios de transporte tornaram acessíveis os lugares distantes e as tecnologias multiplicaram as possibilidades de acesso às imagens e às narrativas sobre esses espaços e culturas. Nesse contexto, o viajante, paulatinamente, foi dando lugar ao turista de massas. Assim como a Literatura de Viagens foi se reduzindo à banalização dos guias e relatos de propaganda turística em diferentes mídias. Ao tratar do viajante, Cristóvão propõe uma tipologia em que considera a existência de cinco categorias: o peregrino, o comerciante, o explorador, o viajante de formação ou de erudição e o viajante personagem de ficção.

A partir da leitura de textos de escritores-viajantes, Cecília Meireles comparativamente a Octavio Paz, pretende-se mostrar, neste texto, que foi possível a renovação da Literatura de Viagens no século XX, menos pela referencialidade de novas e exóticas paisagens e culturas, que pela singularidade do olhar do escritor-viajante e pela transfiguração estética com que plasma suas experiências.

Na tipologia proposta por Cristóvão, Cecília e Paz se enquadram como "viajantes de erudição ou de formação", cujas viagens têm na aquisição de conhecimentos seu objetivo maior. Diferentemente do turista de massas, o olhar do escritor-viajante modela-se por uma linguagem que não é mero instrumento de difusão de lugares-comuns, mas é tocada pela poesia. Em Cecília Meireles 
evidenciam-se também traços do peregrino, não propriamente no sentido religioso do termo, mas como viajante que busca, a partir da observação da beleza de paisagens e monumentos e da diversidade cultural, alçar-se do plano material imediato a um plano espiritual, pela via da experiência sensível, essencialmente sinestésica em Cecília. Assim, na medida em que a obra da poeta entrelaça o sensível e o inteligível, nossa abordagem busca também perceber ressonâncias platônicas, especialmente referentes à Teoria das Reminiscências, em textos de viagem de Cecília Meireles.

Neste trabalho, nossa análise centrar-se-á em crônicas que têm como referência a viagem que Cecília Meireles fez à Índia em I953. Porém, não nos deteremos especificamente na maneira como aspectos das tradições religiosas e literárias indianas e da cultura em geral daquele país influenciaram o pensamento da poeta e são elaborados nesses textos, o que já foi realizado, com muita propriedade, por Dilip Loundo, no ensaio "Cecília Meireles e a Índia: viagem e meditação poética", publicado na coletânea organizada por Gouvêa (2007). De início, trataremos do tema da aeridade no contexto da viagem à Índia. Aeridade em duplo sentido: literalmente, como viajante da era do avião, que vê com otimismo esse novo meio de transporte; em sentido figurado, observadora atenta e incomum de detalhes e que promove, em seu silêncio, um intenso diálogo íntimo com o que está à sua volta a partir de referências que mostram vasta erudição. Para esse propósito utilizaremos, como referencial teórico, o ensaio "Leitura e Contemplação" de Octavio Paz (I99I), publicado em Convergências, em que o crítico e poeta mexicano trata da glossolalia.

Em seguida, nos deteremos em algumas crônicas de Cecília Meireles sobre suas andanças peregrinas pela Índia, comparativamente a observações feitas por Octavio Paz (1996) no livro Vislumbres da Índia. A análise das crônicas e a comparação com fragmentos dessa obra do poeta mexicano centrar-se-ão em duas observações feitas por Dilip Loundo sobre as crônicas de viagem da 
Viagem à Índia: Cecília Meireles e Octavio Paz

LUÍS ANTÔNIO CONTATORI ROMANO

poeta brasileira: são uma continuação do discurso poético e mostram um olhar impressionista sobre os lugares visitados. A discussão sobre a primeira afirmação tomará como referência a crônica "Luz e Som de Bombaim", e, além da comparação com excertos de Vislumbres da Índia, iremos nos respaldar na própria concepção de linguagem poética de Paz (1982), explicitada em O Arco e a Lira. A discussão sobre a segunda afirmação de Loundo centrar-se-á nas crônicas "Recordação de Acbar" e "Vimos o Taj Mahal", ambas publicadas no $2^{0}$ tomo das Crônicas de Viagem (I999), comparativamente a excertos da obra memorialística de Paz centrada em sua vivência indiana.

Iniciemos pela abordagem do tema da aeridade, comentando três das crônicas que tratam do percurso entre Roma e Bombaim. Elas não estão apresentadas numa possível ordem cronológica do trajeto no $2^{\circ}$ tomo da coletânea Crônicas de Viagem, o que é perfeitamente compreensível, dado que a viagem é apenas uma referência inicial, transfigurada pelo intenso lirismo da cronista. No entanto, para efeito de análise, tentaremos restabelecer aqui uma suposta ordem cronológica que inclui duas variações de uma mesma parte do percurso.

Na crônica "Direção Leste", Cecília (I999, I5I-I54) descreve os momentos que antecederam a partida no aeroporto de Roma, as últimas palavras ouvidas em italiano, freiras que se despedem de companheiras que partem para o Oriente, passageiros, atitudes, paisagens... A cena do embarque trata da solidão, do isolamento do mundo de quem viaja na cápsula aérea, o que sugere o autofechamento da alma que se prepara para fazer a viagem de retorno ao mundo etéreo, tal como apresentada por Platão (I972), pela voz de Sócrates, no Fédon. Porém, trata-se de uma alma "que recorda", que leva consigo sua experiência terrena. Vejamos:

Em sonho caminhamos. Apenas em sonho lúcido, que recorda. Ninguém sabe de nós, a esta hora. Há delícia em pensar que ninguém sabe de nós. Aconteça o que acontecer, 
Recorda, inclusive, que a própria partida foi precedida de intensa expectativa por essa nova realidade a ser conhecida: uma senhora francesa, sentada ao lado da cronista no restaurante romano, diz: "Deve ser uma coisa fantástica, a Índia!” (I999, I51). Se há recordação nessa partida, há também imensa curiosidade e um olhar atento a tudo que a cerca. Na poltrona ao lado, a cronista se entretém em observar uma passageira rosada, norte-americana, que calça umas “fantásticas sandálias douradas" (I999, I5I), desaparecidas momentaneamente sob o cobertor.

Amanhece e o avião se aproxima do Cairo, prepara-se para pousar, a visão aérea da Esfinge faz com que os passageiros despertem. Um dos indícios do dia que surge é o reluzir das sandálias douradas da passageira norte-americana, que reaparecerá em outros textos em que trata dessa viagem aérea. Nesse texto, faz-se presente a reflexão sobre a existência de dois tipos de viajantes aéreos. Um deles é aquele que se entretém com as mínimas coisas e fecha-se num aprendizado silencioso, aproximando-se do conceito de "viajante" e da concepção de filósofo exposta no Fédon, como aquele que é amigo do saber e se prepara para a morte. O outro tipo é o do viajante "evadido", que dorme ou espera pela passagem do tempo, pois deseja chegar ao destino e não lhe interessa o percurso, este se aproxima do conceito de "turista", tal como a poeta desenvolve em outros de seus textos de viagem, especialmente na crônica "Roma, turistas e viajantes" (Meireles, I999). Vejamos um excerto:

Todos se entusiasmam à idéia de que, dentro de pouco tempo, desceremos no Cairo, tanto é certo que o amor pelas viagens, para quase toda a gente, não está no viajar, mas 
Viagem à Índia: Cecília Meireles e Octavio Paz

Luís ANTONNIO CONTATORI ROMANO

no chegar. O vôo noturno e solitário, o arrebatamento, a grandeza do desamparo entre o céu e a terra não causam sempre um fervoroso êxtase; mas a idéia de pousar de novo os pés no chão, de sentir próximas todas as coisas cotidianas: a árvore e a porta, a mesa, a cadeira, o degrau, - isso faz desabrochar um sorriso ardente, nos lábios mal acordados. (Meireles, I999, I53-I54)

Na crônica "Ano Muito Bom”, Meireles (I999, I2I-I23) narra a passagem de ano durante a viagem aérea em direção à Índia. A narradora observa e ouve as diferentes expectativas e intenções de seus vizinhos de assento sobre o país a ser visitado. Ao seu lado, reaparece a rosada norte-americana, de sandálias douradas, que diz que irá dançar em Bombaim na passagem do ano. Ao perceber a proximidade do pouso em Bombaim passa a perfumar-se. O ano, entretanto, se inicia ainda sobre o mar, dadas as diferenças de fuso horário: “O ano, porém, chegava ainda mais depressa que Bombaim. E em dado momento soubemos todos que, malgrado as extravagâncias dos relógios, era meia-noite, entre as estrelas e o mar." (I999, I22). Ocidentais e orientais unem-se quando se convenciona que é meia-noite, embora seja outro o calendário na Índia. Vejamos como ela descreve a aeromoça, a quem atribui asas, como a um anjo cosmopolita, anglo-indiano, que anuncia o Natal, o comandante que cumprimenta os passageiros e esses que se dão as mãos e expressam mútuos desejos de felicidade em diferentes línguas:

E a aeromoça, de belíssimos olhos, abria e fechava as asas do seu sári azul servindonos suas pequeninas oferendas. E o comandante vinha participar da festa, que era ao mesmo tempo de começo e de fim.

E de repente vimos que estávamos todos de mãos dadas, e todos formulávamos nossos votos mútuos, cada um na sua língua, todos num idioma comum de esperança e ternura. (Meireles, I999, I22) 
Na crônica "Pelo Mahatma”, Meireles (I999, I55-158) dá continuidade ao percurso aéreo apresentado em "Direção Leste", sendo uma variante de "Ano muito bom", porém, a partir do momento em que o avião decola do Cairo, onde fez escala. Reaparecem a norte-americana de sandálias douradas, as freiras e a francesa, que conheceu no aeroporto de Roma. A moça americana é objeto de seu minucioso olhar, sua expectativa por dançar em Bombaim parece enredar a cronista em divagações. Olhar centrado em pequenas vaidades que parecem materializar o efêmero:

Há uma grande paz a bordo. Apenas a moça das sandálias douradas custa a encontrar posição confortável, custa a encontrar uma ondulação agradável para o penteado, e aroma suficiente na água-de-colônia das suas infindáveis abluções. (Meireles, I999, I55)

É a última noite do ano, - e a moça das sandálias douradas anuncia ao seu conhecido:

“Dançaremos em Bombaim!” (Meireles, I999, 157)

Na crônica "Luz e Som de Bombaim” (Meireles, I999, I59-I63), a moça americana de "pés dourados" desaparecerá entre a multidão, esquecendo sua pequena carteira em alguma parte da sala de desembarque. Efêmera que é, a imagem da passageira insiste, entretanto, em permanecer na memória da cronista, inscrevendo-se metonimicamente como a luminosidade que clareia a noite sobre as margens do Mediterrâneo e sobre o oceano na viagem ao Oriente: “Desaparece a passageira de pés dourados, deixando esquecida em qualquer parte a pequena carteira que trazia, tão cintilante quanto as suas sandálias. [...] Como uma estrela que tivesse entrado no aeroporto.” (Meireles, I999, I59)

Se a reluzente passageira enreda em pensamentos a cronista, ainda no relato da viagem, em "Pelo Mahatma", a francesa, que apenas conhecera no aeroporto de Roma, é referida como amiga, o que parece indicar uma empatia, 
Viagem à Índia: Cecília Meireles e Octavio Paz

LuÍS ANTÔNIO CONTATORI ROMANO

finalidade de propósitos e proximidade de olhares: "Minha amiga francesa, que durante a viagem, tantas vezes se deslumbrou com as cores, as distâncias, as visões do passado, deseja, acima de tudo, entender o sentimento místico da Índia.” (Meireles, I999, I57)

Em "Pelo Mahatma”, é retomado o tema da passagem de ano sobre o oceano, a mensagem do comandante, as saudações em diferentes idiomas e a chegada a Bombaim na madrugada de $\mathrm{I}^{\mathrm{o}}$ de janeiro de $\mathrm{I} 953$. Vejamos um excerto dessa crônica:

O comandante vem brindar com os passageiros, porque o avião começa a descer em Bombaim. E os passageiros levantam-se, e, de mãos dadas, cantam as canções que sabem, cada um na sua língua, e todos trocam votos de felicidade, nesta meia-noite de 3I de dezembro. (Meireles, I999, I58)

As saudações de Ano Novo, em diferentes idiomas que nem sempre as pessoas conhecem, mas são capazes de entender, sugere a ideia da motivação da linguagem, da conexão inerente entre som e sentido; claro que aqui temos um contexto específico e universal (ou, pelo menos, ocidental), que é o dos festejos da passagem do ano. Porém, como a cena transfigurada na escrita da cronista sugere uma espécie de êxtase, algo equivalente a uma experiência poética, vale a pena uma incursão pela temática do "falar em línguas", a glossolalia, de que trata Octavio Paz (I99I).

No ensaio "Leitura e Contemplação", de Convergências, Paz (I99I) argumenta que a poesia nasce da antiga crença mágica na identidade entre a palavra e aquilo que ela nomeia, o que Paz articula à glossolalia. Embora esta se manifeste primordialmente em ritos e atos litúrgicos, a experiência não é exclusivamente religiosa, está presente também na poesia, que considera uma espécie de dança de sílabas e de vozes rítmicas irredutíveis a conceitos: 
A poesia, entendida como alquimia verbal, supõe uma relação inerente entre os sons e os significados, que subsiste e ultrapassa a relação arbitrária entre significante e significado convencionada em qualquer linguagem, tal como pressuposta pela Linguística saussuriana. Para Octavio Paz (I99I), a poesia transpõe o domínio dos significados, mostra realidades indizíveis e intraduzíveis, mas não incompreensíveis e, nesse sentido, se aproxima da suposta experiência mística, como aquela que se manifesta na glossolalia. É forma pura como esta, porém, diferentemente desta, a experiência poética realizada em poema ou prosa-poética passa pela elaboração reflexiva, é, também, pensamento abstrato, como considera Paul Valéry (2007).

Octavio Paz (I99I, I2) afirma que a poesia se aproxima da linguagem dos deuses, pois produz determinada realidade, enquanto a prosa representa a realidade. Assim, a poesia se aproximaria do êxtase religioso. Há nessa consideração uma relação com o delírio poético de que trata Platão (I960) no Fedro. Atribuindo voz a Sócrates, este considera a existência dos delírios divinos da arte profética, religioso, poético e erótico. Paz considera, no entanto, que o delírio poético vertido em forma poética torna-se "objeto artificial", ressoa a si mesmo mais que o êxtase original de que é a tradução metafórica, mas pode ressuscitar, na leitura, novo delírio poético, não idêntico ao que motivou sua criação e nem ao expresso pelo eu-lírico, mas o do outro, que se comunica com os dois outros. Vejamos um excerto de Paz (I99I, 42): 
Viagem à Índia: Cecília Meireles e Octavio Paz

LuÍS ANTÔNIO CONTATORI ROMANO

\footnotetext{
O poeta, ao nomear o que sentiu e pensou, não transmite as idéias e sensações originais: apresenta formas e figuras que são combinações rítmicas nas quais o som é inseparável do sentido. Essas formas e figuras, esses poemas, são objetos artificiais, cubos ou esferas de ecos e ressonâncias, que produzem sensações e idéias-sensações semelhantes mas não idênticas às da experiência original. O poema é a metáfora do que o poeta sentiu e pensou. Essa metáfora é a ressurreição da experiência e sua transmutação. A leitura do poema reproduz esse duplo movimento de mudança e ressurreição.
}

Nas crônicas de Cecília, a experiência da passagem do ano no avião entre o Cairo e Bombaim, pela própria recorrência da imagem reconfigurada em diferentes textos, sugere o êxtase poético. Vivência essa em que há compreensão mútua, mesmo na situação babélica da aeronave, como se na canção de cada um o outro derivasse significados da associação direta entre som e sentido, dado o contexto comum em que ocorre. Experiência poética a que a cronista dá forma em sua prosa-poética, a meio caminho entre o "cubo ressonante" do poema e a linguagem representativa da prosa, lembremo-nos de que as crônicas tinham como destino a publicação na imprensa, campo da linguagem prosaica e informativa.

Dilip Loundo (Gouvêa, 2007, I54) afirma que as crônicas de viagem de Cecília Meireles são na prática uma continuação do discurso poético e pouco se assemelham a um diário ou a narrativas de viagem. Vamos partir dessa afirmação para discutir a prosa-lírica de Cecília Meireles com base em considerações de Octavio Paz (I982) sobre as especificidades da linguagem poética.

Em O Arco e a Lira, o poeta e crítico mexicano considera que o poema é um organismo verbal, irrepetível, que contém, suscita ou emite poesia. Diferencia a linguagem da prosa da poética pela metáfora da pedra. Esta pode se transformar em escada ou em escultura. A primeira, como a prosa, se insere no mundo da utilidade; a segunda, como a poesia, é, essencialmente, imagem, ao 
mesmo tempo em que readquire a opacidade das coisas. Vejamos um excerto de O Arco e a Lira:

Na prosa a palavra tende a se identificar com um dos seus possíveis significados, à custa dos outros: ao pão, pão; e ao vinho, vinho. Essa operação é de caráter analítico e não se realiza sem violência, já que a palavra possui vários significados latentes, tem uma certa potencialidade de direções e sentidos. O poeta, em contrapartida, jamais atenta contra a ambigüidade do vocábulo. No poema a linguagem recupera sua originalidade primitiva, mutilada pela redução que lhe impõem a prosa e a fala cotidiana. A reconquista de sua natureza é total e afeta os valores sonoros e plásticos tanto como os valores significativos. [...] O poeta põe em liberdade sua matéria. O prosador aprisionaa. (Paz, I982, 25-26)

Para Octavio Paz (1982) qualquer que seja sua atividade e profissão, artista ou artesão, o homem transforma a matéria-prima: cores, pedras, metais, palavras. Os materiais abandonam o mundo da natureza para ingressar no das obras, isto é, no mundo das significações. Ainda que de uma pedra o homem possa fazer escada ou estátua e ambas possam fazer parte de um mesmo sistema de significações, a transformação que a pedra sofreu na escultura é de natureza diversa da que sofreu na escada. A poesia, em sentido amplo, entendida como a arte de transformar coisas, palavras e sons em imagens, que se materializam em obras, exerce um poder sobre o outro - o espectador ou ouvinte - ao suscitar nele também a produção de imagens. A obra de arte se torna, assim, uma forma peculiar de comunicação.

No âmbito das palavras, a unidade da frase, que na prosa se dá pelo sentido ou significado, é obtida no poema graças ao ritmo, que é tempo originário, temporalidade concreta. O poema é tempo vivo, é passado evocado e recriado no presente, que se torna futuro, se eterniza ao ser reavivado pela leitura. 
Viagem À Índia: Cecília Meireles e Octavio Paz

LUÍS ANTÔNIO CONTATORI ROMANO

Para Octavio Paz, a imagem é um recurso desesperado contra o silêncio que nos invade cada vez que tentamos exprimir a terrível experiência do que nos rodeia. Porque a linguagem é sentido disto ou daquilo e o sentido é o nexo entre o nome e aquilo que nomeamos, nexo, porém, sempre insuficiente, pois nomear é atestar a ausência da coisa nomeada. Assim, pelas palavras somente somos capazes de representar o que nomeamos, o que implica distância entre um e outro. Com a imagem, a distância entre a palavra e a coisa se reduz: o nome e a complexidade do ser nomeado se aproximam. A linguagem prosaica indica, representa, funciona como um estereótipo da coisa. O poema apresenta. Pretende recriar as mil faces da realidade. A imagem poética não explica, convida-nos a recriá-la e, por isso, o dizer do poeta se encarna na comunhão poética.

A palavra poética é a revelação de nossa condição original porque através dela o homem se nomeia outro e, ao mesmo tempo, busca capturar suas mil faces. Assim, torna-se este e aquele, ele mesmo e o outro. Paz (I982) trata de três situações que conjugam sede e satisfação, em que vivemos o êxtase de sermos simultaneamente "fruto e boca": o encontro amoroso, a imagem poética e a teofania, que, em essência, correspondem aos delírios inspirados pelos deuses de que trata Platão (I960) no Fedro.

Como afirma Loundo (2007), a prosa de viagem de Cecília Meireles é poética porque transfigura a experiência da viagem, convertendo-a em imagem e em ritmo. Nesse sentido, a poeta contribui para promover uma renovação no gênero, pois o que interessa não é a prosaica informatividade que o virtual leitor pode encontrar no texto, como aquela que vai buscar numa revista especializada em turismo ou em um guia de viagem. A poeta transforma a experiência nomeada e transfigurada em imagens, cores, ritmos, cuja poesia pode afetar o leitor, elevá-lo também a uma espécie de "delírio poético". 
Vamos nos deter, a seguir, na crônica "Luz e Som de Bombaim" comparativamente a fragmentos de Vislumbres da Índia, ensaio de fundo memorialístico de Octavio Paz (I996), em que este trata da cultura indiana a partir da experiência de haver vivido no país como diplomata mexicano em duas ocasiões, perfazendo mais de seis anos de residência na Índia. Notemos que Octavio Paz e Cecília Meireles viajaram para a Índia em épocas muito próximas. O poeta mexicano fez sua primeira viagem ao país asiático em I951, onde viveu por alguns meses como funcionário da Embaixada do México até ser transferido para o Japão. Retornou como embaixador em I962, permanecendo pouco mais de seis anos em Nova Délhi. Cecília realizou sua única viagem à Índia em I953. Chegou a Bombaim em I $\mathrm{I}^{\circ}$ de janeiro e permaneceu no país até 6 de março de I953, totalizando uma estada de 65 dias. A maior parte desse tempo esteve envolvida com atividades acadêmicas, seja na primeira parte da viagem, que realizou a convite do Primeiro-Ministro Nehru para participar de um Congresso Internacional sobre Gandhi, de 5 a I7 de janeiro de I953, em Nova Délhi, seja na segunda parte, quando acompanhou seu marido, Heitor Grillo, em viagens a trabalho por diferentes cidades do país com propósitos científicos, a serviço do CNPq.

Antes de viajar à Índia pela primeira vez, em I951, Octavio Paz viveu entre I945 e I95I, como funcionário da Embaixada mexicana em Paris. Apresenta uma descrição dessa cidade em que predominam as antíteses que se harmonizam. Vejamos:

Tentava escrever e, sobretudo, explorava essa cidade que é talvez o exemplo mais belo do gênio de nossa civilização: sólida sem ser pesada, grande sem gigantismo, ligada à terra, mas com vontade de vôo. Uma cidade onde a moderação rege com a mesma altivez, suave e inquebrantável, os excessos do corpo e os da cabeça. Em seus momentos mais felizes - uma praça, uma avenida, um conjunto de edifícios -, a tensão que a habita resolve-se em harmonia. Prazer para os olhos e para a mente. (Paz, I996, 9) 
Viagem à Índia: Cecília Meireles e Octavio Paz

LUÍS ANTONNIO CONTATORI ROMANO

Octavio Paz entrou na Índia, em I95I, pelo porto de Bombaim. Cidade onde também desembarca, por via aérea, Cecília Meireles, em $\mathrm{I}^{\mathrm{o}}$ de janeiro de I953. Ambos deixaram registros desse primeiro olhar. Vejamos o registro de Octavio Paz:

Uma vez em terra, rodeados por uma multidão que vociferava em inglês e em várias línguas nativas, percorremos uns cinqüenta metros do sujo cais e chegamos ao desordenado edifício da alfândega. Era enorme. O calor era sufocante e a desordem, indescritível. Com dificuldade identifiquei minha pequena bagagem e submeti-me ao embaraçoso interrogatório do funcionário alfandegário. Creio que a Índia e o México têm os piores serviços aduaneiros do mundo. (Paz, I996, I5)

Lembremos agora o registro de Cecília em "Luz e Som de Bombaim”:

Depois de tantas horas de vôo sobre mares e desertos, o chão de Bombaim, confundido na noite, é território imaginário, por onde os passos dos fatigados aeronautas erram sem firmeza nem precisão. Na sombra pastosa de uma atmosfera úmida e morna, já não nos governamos muito; é mesmo o destino que nos vai conduzindo, através de um sistema de portas, mesas, balcões, guichês...

$[\ldots]$

Mas agora é a voz muito conscienciosa da funcionária, à sombra dos seus belos olhos, docemente franjados: “... tudo de uso pessoal?” _ “De uso pessoal”. Lança um arabesco de giz em cada mala. E mergulhamos na noite, na primeira noite do ano, ao longo da cidade que parece fluida como um rio, neste nosso deslizar pela estrada. Às vezes, sentimos que há palácios, varandas, manchas altas de arquitetura. Tudo, porém, desliza, foge, exatamente como na água do sonho. (Meireles, I999, I59) 
A chegada de Paz à Índia ocorre durante o dia, enquanto Cecília chega à noite. Paz entra pelo porto e Cecília pelo aeroporto. Entretanto, os relatos registram quatro elementos comuns: o espaço da alfândega, o funcionário alfandegário, o clima e a bagagem. Enquanto Paz parece revelar, num primeiro impacto, um olhar eurocêntrico sobre esses elementos, marcado por uma atitude de "fobia", que desvaloriza a cultura do espaço estrangeiro em relação à cultura europeia que ele assimilou, a poeta brasileira revela empatia com o universo no qual penetra, uma atitude de "filia", em que considera a realidade cultural estrangeira igualmente positiva em relação à de seu espaço de origem. "Fobia" e "filia" são duas das quatro categorias, que também incluem a "mania" e o "cosmopolitismo", que Machado e Pageaux (1988) propõem como instrumentos de compreensão da representação do espaço estrangeiro em relatos de viagem e em narrativas literárias que incluem o tema da viagem.

No registro de Octavio Paz, o edifício da alfândega é caótico, o funcionário é desagradável, o calor é sufocante e a bagagem é encontrada com dificuldade, juízos que sinalizam para uma impressão de desordem e confusão sobre o espaço estrangeiro, que o torna inferior ao paradigma ocidental. Embora pareça haver uma mistura de repulsa e desejo ao penetrar nesse espaço novo e familiar, em algum aspecto próximo do país de origem do escritor, também marginal em relação ao espaço europeu, que parece ser sua referência de valor.

No registro de Cecília Meireles, o clima úmido e morno não é visto negativamente, contribui para promover uma identificação ou mesmo uma dissolução do narrador-lírico no espaço estrangeiro em que penetra: o eu já não se governa, é o destino que o conduz por entre portas, janelas, guichês... As malas parecem facilmente acessíveis, a funcionária alfandegária é solícita e seu gesto de assinalar a mala que libera é visto poeticamente: ela "lança um arabesco de giz em cada mala". 
Viagem à Índia: Cecília Meireles e Octavio Paz

LuÍS ANTÔNIO CONTATORI ROMANO

À saída dos respectivos locais de desembarque, comparemos as impressões dos dois poetas. Vejamos antes o registro de Paz, que observa, com grande estranheza, inicialmente ainda do mar, o hotel Taj Mahal em que se hospedará, erguido, como irá saber já em terra, ao contrário pelos construtores indianos, devido a um erro de interpretação da planta, elaborada na Europa. O hotel foi construído com a fachada voltada não para o mar, mas para a cidade, o que Paz interpreta como um ato falho (I996, I4), um desejo inconsciente de a Índia dar às costas para o exterior, que, à época da construção, era representado pelo domínio britânico, e voltar-se para dentro. A seguir, temos uma descrição das primeiras impressões de Paz a partir de um passeio por Bombaim. Descrições cuja figura dominante é também a antítese, porém, diferentemente da descrição de Paris, em que as antíteses se harmonizam, aqui elas revelam um profundo estranhamento, como se aquela realidade lhe fosse excessiva e, por isso mesmo, o tocasse no íntimo, não parava de querer contemplá-la, experimentála pelos sentidos. Olhar que parece mostrar um esquecimento de referências sobre a realidade vista pela primeira vez. Certamente, Octavio Paz não viajava à Índia nu de informações, agradou-o, de início, a transferência para o país, pela possibilidade de constatar seus conhecimentos sobre a arte e a cultura hindus. No sentido em que foi teorizado por Pinto-Correia, no ensaio "Deslumbramento, horror e fantasia. O olhar ingénuo na Literatura de Viagens” (2003), é um olhar, sem dúvida, deslumbrado, mas não se trata de olhar ingênuo, pois este pressupõe um maior aprisionamento do viajante à sua própria realidade cultural, onde buscaria termos de comparação para tornar familiar a nova realidade que desconhece. Neste caso, talvez fosse mais pertinente a aplicação da expressão "olhar inocente", tal como o compreende Michel Onfray (2009, 59-60):

A inocência supõe o esquecimento do que se leu, ouviu, aprendeu. Não a negação, nem

o abandono, mas a colocação à distância daquilo que parasita uma relação direta entre 
CARACOL 3 / DOSSIÊ

o espetáculo de um lugar e nós. [...] a viagem solicita o desejo e o prazer da alteridade; não a diferença facilmente assimilável, mas a verdadeira resistência, a franca oposição, a dessemelhança maior e fundamental.

Olhar inocente a quem a realidade vislumbrada pela primeira vez desconcerta pela novidade de paisagens e pessoas e que move à contemplação. Contemplação que o próprio Paz (I99I, 42) define como "a mais alta forma da compreensão, porque abrange ver e entender". Ou, ao menos, a busca por entender. A configuração que Paz dá a essa experiência primeira de deslumbramento, excesso e contemplação é a de imagens em movimento, mistura de poema e cinema, síntese de um olhar sinestésico que se move embevecido pelo inesperado. Vejamos um excerto:

ao atravessar uma esquina, a aparição de uma jovem como uma flor que se entreabre, rajadas de fedores, matérias em decomposição, odores de perfumes frescos e puros, pequenos postos de vendedores de cocos e fatias de abacaxis, desocupados andrajosos sem ofício nem benefício, um bando de adolescentes como um tropel de cervos, (Paz, 1996, I6)

Já em Cecília Meireles, na estrada que toma a partir da saída do aeroporto, a paisagem e o clima parecem sugerir um sentimento de densa fluidez, de dissolução de homens e coisas: “Às vezes, sentimos que há palácios, varandas, manchas altas de arquitetura. Tudo, porém, desliza, foge, exatamente como na água do sonho." (I999, I59) No táxi, o denso fluir pela cidade é acompanhado por uma livre associação de palavras: Bombaim, deusa Mumba, Bumba-meu-Boi, danças noturnas; talvez desencadeada pela presença imaginária da dançarina de "pés dourados", a passageira-de-passagem que se sentava ao seu lado no avião. A dança imaginária é interrompida quando chega ao hotel. Novamente 
Viagem à Índia: Cecília Meireles e Octavio Paz

LuÍS ANTÔNIO CONTATORI ROMANO

pode ser evidenciada a serena "filia" da cronista em relação ao país estrangeiro. Quando o carro para, pessoas se levantam do chão para pedir esmolas. Sob o olhar da cronista transparece forte impressão de unicidade entre os mendigos, o chão de onde se levantam e do qual parecem fazer parte e ela própria, todos unidos por uma substância comum, que é a poeira. Nota-se ainda um olhar preparado, pouco ingênuo, embora seja um primeiro olhar, capaz de operar relações intertextuais, pois as cenas que vê são um reconhecimento daquilo que já foi conhecido em pinturas e livros. A partir do que presencia é ainda capaz de efabular, pois os olhares que encontra nos mendigos são os mesmos ao longo do tempo, são universais. Vejamos um excerto:

E, como o carro pára, logo se levantam do chão muitos vultos sombrios, que se aproximam rastejantes, a esmolar, de mão estendida. Estavam ali, integrados no chão, como poeira adormecida, e como poeira se levantam, com vulto humano, e para nós se dirigem - poeira também. E, no meio da noite, a cena é vaga, triste e grandiosa: na opaca escuridão que ao mesmo tempo é terra, pano, pele, brilham grandes olhos patéticos, uns olhos que já vimos em pinturas e imagens milenares, com um olhar que existe desde a raiz do Tempo. (Meireles, I999, I60)

Os mesmos elementos da poeira e do mendigo, ou homem santo, reaparecem no registro de Octavio Paz (I996, I6) - aparentemente escrito mais próximo dos acontecimentos ou, ao menos, que simula essa proximidade -, porém sob a impressão do negativo. Vejamos um fragmento: "[...] batalhas de buzinadas entre um táxi e um ônibus empoeirado, mais bicicletas, outras vacas e outro beato seminu e maltrapilho."

A visão a respeito dos mendigos da Índia em Paz recebe ainda um tratamento menos subjetivo e sinestésico e mais informativo e prosaico em outro momento da mesma obra. Imaginamos que o registro tenha sido feito muitos 
anos depois de sua longa estada no país, tempo da escritura de Vislumbres da Índia, quando reflete sobre o cerrado círculo de famílias que se configura na tradicional instituição das castas, que, por encerrar o indivíduo, deixa a ele um único caminho alternativo além da morte:

[...] a renúncia ao mundo, a consagração à vida religiosa do ermitão e do contemplativo, que percorre os caminhos seminu e sem nenhuma outra propriedade além de uma vasilha de latão para recolher as esmolas e os alimentos. (Paz, I996, 62)

Esse é o sadu, um dos tipos de mendigos hindus, além dos necessitados e dos enfermos. Considera ainda Paz que entre os sadus há não só homens santos, mas também pícaros e lunáticos. Poderíamos ainda pensar em acrescentar, na atualidade, aqueles que assim se mostram por obterem do turismo uma forma de sobrevivência, assim como, contemporaneamente, encontramos, por exemplo, às portas do Coliseu de Roma, homens travestidos de soldados romanos que se oferecem às fotografias dos turistas. Ou dervixes que se apresentam em casas de espetáculos turcas para o deleite de turistas estrangeiros.

Como já foi mencionado, Cecília chega a Bombaim à noite, em seu olhar poético sobre o novo espaço ressalta a ideia de integração, a entrada em lugar há muito "conhecido", que parece corresponder ao que foi imaginado sobre ele e que é ainda capaz de ativar a capacidade fabuladora da cronista. A chegada de Paz ocorre durante o dia e seu olhar não é menos poético que o de Cecília, mas em seus registros transparece a distância entre os mundos ocidental e oriental, uma forte sensação de estranhamento. E uma tentativa por encontrar, na contemplação, uma explicação para a nova realidade vislumbrada. Estranhamento e desejo de contemplação que o arrastam num flanar incessante pela cidade. Mal se instala no hotel, procura a rua e seu vagar por Bombaim se prolonga pela noite adentro. Vejamos: 
Viagem à Índia: Cecília Meireles e Octavio Paz

LuÍS ANTÔNIO CONTATORI ROMANO

A noite me atraía e decidi dar outro passeio pela grande avenida que margeia o cais. Era uma zona calma. No céu ardiam silenciosamente as estrelas. Sentei-me ao pé de uma grande árvore, estátua da noite, e tentei fazer um resumo de tudo o que havia visto, ouvido, cheirado e sentido: enjôo, horror, estupor, assombro, alegria, entusiasmo, náuseas, invencível atração. (Paz, I996, I8)

Na crônica de Cecília, a primeira noite no hotel é acompanhada por uma sensação de denso calor, que parece aderir à decoração vermelha do quarto. Abre a janela e passa a contemplar o azul do céu estrelado e a ouvir o crocitar dos corvos. O nascer do dia, diante da janela do quarto de hotel, move comparações com paisagens brasileiras: "E aparecem crianças que vêm ver o dia. $\mathrm{E}$ o dia é verde, azul, chamejante, como no Brasil, com mangueiras e bananeiras, - rumoroso, povoado, colorido." (Meireles, I999, I6I) A paisagem matinal é marcada principalmente pela variedade e colorido das roupas. As cores intensas dos sáris parecem dissolver mulheres e paisagens: "A mulher-flor que passa envolta em sedas róseas e verdes, e a mulher-crepúsculo, com seus véus amarelos e roxos..." (1999, I6I). Das cores das roupas, a narradora passa a descrever o movimento rítmico dos veículos, depois o ruído da variedade de falares. Cresce a turba em movimento. Observemos a concatenação das falas, como a sequência de frases iniciadas anaforicamente pelo verbo "falar" tece uma rede de comunicação possível, ao olhar da cronista, nessa multiplicidade de tipos sociais, linguísticos e étnicos:

Porque é uma turba tão rumorosa quanto colorida. Falam as crianças, a brincar, de uma janela para outra, ou em redor dos arbustos do jardim. Fala a menina a pular corda, com a outra menina que a observa, sentada num degrau. Fala o porteiro com os passantes; falam os passantes com os seus companheiros; falam os que vão nos carros com os que estão na rua; falam os vendedores, à sombra das colunatas; falam os que 

tivos, puros ou mesclados, com um ritmo martelado e rápido, com uma inflexão dura que as palavras, em si, não têm. (Meireles, I999, 162)

Lembremos que, no registro de Octavio Paz, ao chegar ao porto de Bombaim, as tensões da Índia, que considera sem síntese possível, se expressam, por exemplo, pela imagem da multidão que "vociferava em inglês e em várias línguas nativas" (I996, I5). Enquanto de sua janela do quarto de hotel em Bombaim, a narradora ceciliana, ao observar a multidão que vai enchendo as ruas da cidade ao nascer do dia, tece verdadeira rede de falares. Indica assim a possibilidade de comunicação na Babel multicultural que é a Índia, imagem que parece sintetizar a noção de glossolalia de que trata Paz (I99I) no ensaio “Leitura e Contemplação”. Esse olhar que percebe a integração entre pessoas e paisagens, a despeito da multiplicidade, foi observado pelo crítico Darcy Damasceno num comentário sobre os Poemas Escritos na Índia, perfeitamente aplicável também às crônicas sobre a Índia. Vejamos:

Malgrado a variedade do mundo concreto (riqueza cromática, embriaguez de aromas, multiplicidade de seres animados) o ser humano integra-se numa paisagem de que não se dissocia. Ser humano e natureza constituem um mundo circular, onde cada coisa é em si a harmonia do todo. (Damasceno, 1967, I32)

Em meio à multidão e às mulheres de sáris coloridos, há uma referência a uma pobre menina indiana, coberta de brincos e pulseiras, cujo sári está descolorido:

[...] pára no passeio, sozinha, a olhar a multidão que ondula, a sorver pelos seus tristes, imensos olhos, o panorama efêmero e multicor do mundo. Lentamente, leva à boca 
Viagem à Índia: Cecília Meireles e Octavio Paz

LuÍS ANTÔNIO CONTATORI ROMANO

uma fruta amarela, que morde, embevecida. Uma fruta de polpa rósea, cheia de duros grãos, que aqui se chama guava, e é goiaba, no Brasil. (Meireles, I999, I62-I63).

A goiaba tece a ligação com o Brasil e possibilita a leitura como sendo a de uma representação espelhada, em que a cronista se contempla ao realizar o desejo de menina de conhecer a Índia, país pelo qual revela admiração desde os seus primeiros livros, além da influência de Tagore e dos livros sagrados do hinduísmo, como admite Dilip Loundo (2007, I3I), ao afirmar que "o lirismo filosófico de Cecília Meireles constitui uma expressão das mais significativas de uma presença orgânica - e por que não dizer antropofágica? - do pensamento indiano na América Latina.” Assim, a menina parece ser a variante indiana dentro da multiplicidade do ser da poeta, que dá mostras de sentir-se um pouco descolorida e muito embevecida diante de tão rico cenário a oferecer-se às suas experiências dos sentidos.

Interessante observar ainda que enquanto Paz aproxima o caos da alfândega indiana ao caos da alfândega em seu próprio país, em Cecília a ideia de brasilidade conduz à impressão de serena unicidade entre povos de diferentes nações, simbolizada pelas cores e frutas comuns entre as paisagens indiana e brasileira.

A crônica se encerra com a retomada da persistente referência aos corvos que sobrevoam a multidão. A ideia de efemeridade da vida é enfatizada pelo paralelo que tece entre o movimento da multidão pela rua, metonímia da terra, do pó de que somos feitos; e o movimento dos corvos pelos ares, metáfora do fluxo temporal, que coloca essas aves como agentes da natureza sempre a se refazer. São elas que devolvem a multidão ao ciclo natural: "E enquanto a multidão humana, viva e ruidosa, cruza as ruas de Bombaim, os crocitantes corvos cruzam os ares, desabridos, ansiosos pelos mortos, que são o seu sustento." (Meireles, I999, I63) 
Esta visão se aproxima do Zoroastrismo, antiga religião monoteísta que surgiu na antiga Pérsia por volta do século VI a.C. Os pársis nomeiam seu deus de Ahura Mazda, cujo símbolo é o fogo, por isso em seus templos uma tocha de fogo deve permanecer constantemente acesa, o mais famoso deles está na cidade de Yazd, no atual Irã. O Zoroastrismo acredita na existência de um Bem e de um Mal, assim como de um julgamento final e destinos diferentes para as almas. Essa religião parece estar na origem do Judaísmo, do Cristianismo e do Islamismo. Os pársis acreditam que o corpo humano é puro, porém, ao morrer, a alma o abandona após três dias, tornando-o impuro. Ao final desse período, o corpo é levado do templo para as Torres do Silêncio, para que os corvos e outras aves de rapina se alimentem dele. Dessa forma, as aves impedem que o corpo, tornado impuro ao ser abandonado pela alma, polua a natureza, que é pura. Além disso, os mortos retornam ao ciclo natural da vida ao serem devorados pelos corvos. Após a invasão muçulmana na Pérsia, muitos pársis encontraram refúgio na Índia. Em Bombaim existem também as Torres do Silêncio, onde os adeptos do zoroastrismo depositam seus mortos. Ao apresentar o movimento da multidão em Bombaim, a cronista nela coloca os pársis. Parece, assim, como diria Loundo, antropofagizar um aspecto do multiculturalismo indiano. Na presença dos corvos parece estar pressuposta a compreensão da unicidade fundamental entre homens e natureza. Assim, os corvos, ao se alimentarem dos cadáveres, reintegram-nos ao ciclo da vida.

Embora Chevalier e Gheerbrant (2009, 293-295), no verbete sobre os corvos, não façam referência à crença dos pársis, assinalam que, em geral, a acepção negativa do corvo é moderna na Europa e estritamente localizada em outros lugares. "É encontrada, por exemplo, na Índia, onde o Mahabarata compara a corvos os mensageiros da morte. E, talvez, no Laos, onde a água contaminada pelos corvos é imprópria para as aspersões rituais." Entretanto, na maior parte das crenças, “o corvo aparece como um herói solitário, muita vez demiurgo ou 
Viagem À Índia: Cecília Meireles e Octavio Paz

LuÍS ANTÔNIO CONTATORI ROMANO

mensageiro divino, guia, em todo caso, e, até, guia das almas na última viagem, pois que, psicopompo que é, ele penetra, sem se perder, o segredo das trevas."

Na crônica de Cecília, os corvos, ao se alimentarem dos mortos, convertem a efemeridade da vida individual na eternidade da vida que se reproduz no ciclo natural. Essa dialética entre efêmero e eterno pode ser também percebida na arte hindu. Octavio Paz (1996, 25-26) define a arquitetura e a escultura hindus como "dança esculpida". Alfredo Bosi, no ensaio "Em Torno da Poesia de Cecília Meireles" (Gouvêa, 2007, 27), compara poemas de Cecília sobre a Itália e sobre a Índia. Para o crítico, na Itália a obra de arte parece ser dotada de uma solidez que sugere a eternidade, já na Índia todas as formas da matéria parecem luxuriantes, efêmeras.

A Itália se caracteriza principalmente pela arte escultórica, que perdura, mesmo sob a forma de ruína; remete a uma noção de tempo em que é importante a concepção processual e cronológica da História, ligada à ideia de que esta se encaminharia para uma finalidade. Na Índia sobressai a arte dos rendados, dos detalhes exuberantes, do movimento. Mesmo as artes escultórica e arquitetônica sugerem fluidez, remetem a outra noção de tempo, concebido como Maya, sonho de Brama.

Octavio Paz (1996, I63-I7I) trata das diferentes concepções de tempo na tradição greco-romana, no cristianismo e no hinduísmo. A concepção grecoromana pode ser exemplificada com a viagem mítica de Ulisses, que é viagem de retorno, ao término da qual ele reencontra sua terra, seu lar e sua esposa, que não envelheceu, mesmo tendo-se passado mais de vinte anos. Imagem do tempo mítico, tempo circular do eterno retorno, que imita o tempo da natureza e que tem por referência uma organização social relativamente estática. Também Platão e Aristóteles irão conceber o movimento circular como o mais perfeito e o tempo como perfazendo esse movimento. Em Platão, a alma, criada no Empíreo, cai na terra, encarna em um corpo, encarnações que 
se seguirão sucessivamente até que ela reencontre novamente seu lugar no transcendente Mundo das Ideias. Na tradição judaico-cristã, o tempo é retilíneo e finito, caminha para uma finalidade. Introduz a decisão na ação humana, especialmente com o cristianismo, sua noção de tempo pode significar redenção ou perdição. O tempo é instaurado com o pecado original, quando Adão e Eva comem o fruto da árvore proibida, a árvore do conhecimento. Expulsos, dão origem à civilização humana, em que cada membro tem a escolha de salvar-se ou perder-se ao término desse percurso, que é o Juízo Final. Para o hinduísmo, não houve uma única criação, mas muitas, a duração do universo corresponde a um dia de Brama. E o universo dura o que dura o sonho desse deus da criação. Quando desperta, o universo se desvanece. Assim, o tempo é ilusão e o "homem é impermanente como o cosmo, porém em seu fundo está o ser (atman), idêntico ao ser universal.” (Paz, I996, I66). O sentido do tempo está em extinguir-se para integrar-se ao ser pleno. Enquanto a carne renascerá no Juízo Final judaico-cristão e a alma retornará ao Mundo Empíreo para o pensamento grego, no hinduísmo a consciência individual é definitivamente perdida ao se integrar ao Ser depois de cumprida a lei cármica.

Na crônica "Oriente-Ocidente", Meireles (I999, 39-42), durante o percurso de regresso da Índia para Roma, tece comparações entre o estar em cada um desses espaços, sensações que parecem ancoradas numa percepção das diferentes concepções do tempo em cada uma dessas culturas. Vejamos um excerto:

Estar em Roma e pensar na Índia é como sonhar, apenas, que se esteve lá. O principal contraste é a densidade. A Índia é toda fluida: os palácios, os templos, os monumentos são rendados, embrechados, recortados, o céu com o sol e a lua e as estrelas atravessam esses pórticos, andam por esses salões, mesmo quando estejam fechados... Roma, embora transborde dos antigos muros, conserva aquelas paredes que lhe dão majestade, grandeza, mas também uma austera impenetrabilidade. (Meireles, I999, 40) 
Viagem à Índia: Cecília Meireles e Octavio Paz

LuÍS ANTÔNIO CONTATORI ROMANO

Viajar pela Índia, observar seus cenários, de que a cronista, nesse momento, abstrai a presença humana, é como participar da fluidez do sonho de Brama, da efemeridade das coisas - que, embora possam durar séculos na forma de palácios e templos, mimetizam as formas fluidas do sonhar. Entretanto, apesar da impressão de passear entre cenários que parecem materialmente inconsistentes por sua sugestão de leveza e movimento, eles permanecem como imagens na memória da cronista. Já Roma, inúmeras vezes devassada ao longo da História, guarda em si o peso dos tempos, cuja metonímia são as muralhas que a cercam para protegê-la das intenções que rivalizam e, ao fazê-lo, constituem a História. Muralhas em ruínas que condensam a efemeridade das finalidades humanas e a eternidade da História que as significam e preservam.

No ensaio “Cecília Meireles e a Índia: viagem e meditação poética” (2007, I59-I6I), Loundo tece um comentário sobre a atmosfera de revisita que marca a única viagem que Cecília fez à Índia. Aproximação em que opera viva intertextualidade: a Índia vista diretamente através de um olhar rico em referências prévias. Define as crônicas sobre a Índia como impressionistas, pois não trazem marcas precisas de pessoas, de tempo e, às vezes, nem mesmo de espaços. Impressionismo e intemporalidade são dois aspectos considerados por Loundo, que se relacionam ainda com o desapreço, assinalado por ele, de Cecília pelas fotografias, que seria “a cristalização turística do efêmero” (Loundo, 2007, I62). As considerações de Loundo sobre o teor impressionista das crônicas de Cecília encontram respaldo na própria obra da autora. Doze anos antes de viajar à Índia, em texto de I94I, compilado no $5^{\circ}$ tomo das Crônicas de Educação (Meireles, 200ıа, 7-8), com o título de “Lin Yutang e o Turismo", ela resenha o livro A Importância de Viver, do filósofo chinês, e observa: 
Se, como o autor afirma, e infelizmente é verdade, a arte de viajar já se transformou numa indústria e numa indústria rápida, o próprio turista não pode ter ilusões acerca do que lhe cabe ver - em tão curto e sobressaltado tempo, como costuma ser - das excursões.

Um livro de generalizações inócuas, divagações de poeta, sonhos de impressionista pode ser feito nessas condições, porque é obra mais de interiorização que de paisagem, mais de subjetivismo que de objetividade.

O erro grave dos turistas é, pois, pretenderem fazer obra de história, sociologia, política, permanecendo num país algumas poucas semanas, sem o domínio completo de sua língua, e quase sempre com uma total ignorância de sua formação histórica.

Embora a viagem de Cecília Meireles à Índia tenha sido previamente informada pela leitura de obras de literatura e cultura em geral desse país asiático, o tempo que ela ali permaneceu foi relativamente restrito, pouco mais de dois meses. Esse tempo lhe permitiu passear por paisagens, observar atentamente pessoas, lugares, ritos religiosos e outros elementos do multiculturalismo indiano. Não era seu propósito, de fato, escrever um tratado sociológico ou cultural sobre a Índia; as experiências ela transmutava em poesia, poesia em verso e poesia em prosa.

Vamos ainda nos deter em breves comentários sobre três crônicas de Cecília Meireles e a partir delas tecer algumas comparações com observações de Octavio Paz (1996), em Vislumbres da Índia.

Na crônica "Recordação de Acbar", Cecília (I999, 235-238) conta a história do rei Acbar e de seu interesse por diferentes religiões, em versão que se aproxima daquelas repetidas por guias de turismo, ouvida, provavelmente, durante visita à cidadela de Fatehpur-Sikri. Por isso, às vezes, cai no estereótipo, por exemplo, ao afirmar que os pársis adoram o sol, que é apenas uma representação do deus Ahura Mazda. Vejamos alguns fragmentos da crônica: 
Viagem à Índia: Cecília Meireles e Octavio Paz

Luís ANTONNIO CONTATORI ROMANO

Em meio século de reinado, esforçou-se por uma conciliação geral dos homens que o cercavam. Misturou, nas escolas, muçulmanos, hindus e persas. Chamou jesuítas de Goa, para o instruírem no Cristianismo. Ofereceu-lhes muitos presentes, aprende a pronunciar o nome de Jesus, ordenou fossem traduzidos os evangelhos, mandou ensinar a língua persa aos padres e a portuguesa aos filhos, - e as abóbadas de FatehpurSikri repercutiram debates religiosos que, entre cristãos e maometanos, promoveu.

[...] Mas também adorava o sol, como os pársis, e fez a nação aceitar suas interpretações pessoais dos textos islâmicos. (Meireles, I999, 236-237)

Mais adiante, a cronista explicita a fonte das informações como sendo o guia turístico de Fatehpur-Sikri, das quais às vezes duvida: "O imperador - continua o guia - reduziu seu harém a quatro mulheres: uma de cada religião (oh! O grande eclético...) - e enumera: Jodh Bai, Birbal, Maria... Maria era cristã. Portuguesa. (Mas acho que é lenda.)" (Meireles, I999, 238).

Em seu livro, Paz (1996, 47-50) trata do ecletismo religioso do imperador mongol Acbar, muçulmano sufi, que governou entre os séculos XVI e XVII. Apresenta-o como tendo sido a última tentativa, antes do domínio britânico, de conciliar hindus e muçulmanos no subcontinente indiano. O texto, entretanto, é marcado por conter informações mais minuciosas sobre Acbar. Não aparece a idealização romântica do imperador, tão marcante na crônica impressionista de Cecília, como a redução de seu harém a apenas quatro mulheres de etnias ou religiões diferentes. Aliás, Paz atribui a Gêngis Khan o fato de haver se casado com mulheres de diferentes religiões, referência ainda viva entre os muçulmanos sunitas da Índia. Traz informações, por exemplo, do receio que a ascensão de Acbar provocou entre os sunitas, sobre a reprovação destes pelo fato de o imperador haver se casado com uma princesa do Rajastão e sobre a influência hindu em seu governo. Trata ainda do gosto do imperador pela poesia e por debates religiosos. Vejamos um fragmento: 
CARACOL 3 / DOSSIÊ

Em sua juventude, Akbar tinha se interessado pela poesia persa, especialmente pela de Hafiz, muito influenciado pelo panteísmo sufi, impregnado de exaltado erotismo. Talvez o sufismo o tenha levado a interessar-se pelas outras religiões. Fez traduzir o Atharvaveda, o Ramayana e o Mahabharata. Em sua cidade-palácio de Fathpur Sikri uma das obras-primas da arquitetura islâmica -, ergueu uma Sala dos Cultos, na qual se reuniam teólogos e sacerdotes de diversas crenças: muçulmanos sunitas e adeptos de Zoroastro e, finalmente, jesuítas de Goa. Desafiou o descontentamento de muitos muçulmanos influentes e proclamou um decreto chamado A fé divina, no qual se designava árbitro das disputas religiosas. (Paz, I996, 49)

Paz $($ I996, 50) trata também de Xá Jahan, neto de Acbar e construtor do Taj Mahal, mausoléu para guardar os restos mortais de sua esposa Muntaz Mahal, na cidade de Agra. Mostra deste uma visão menos idealizada que a da poeta, que parece, às vezes, novamente reproduzir as informações dos guias de turismo. Observemos em um excerto da crônica “Vimos o Taj Mahal”, como Cecília (I999, 245-249) idealiza a representação de Xá Jahan, em contraste com o que sobre ele informa Octavio Paz:

Oh! Esta dinastia mongol, com uns príncipes inquietos, ciumentos, ambiciosos, que se sucedem precipitadamente, com tanto sangue derramado em seu caminho!

Também assim, a ascensão de Xá Jehan. E enchem-se os olhos de pena, diante do seu retrato, nestas primorosas miniaturas, - tão pulcro, o fino aureolado, como o dos santos, a bela barba pontiaguda, o penacho imperial, o franzido turbante ornado de gemas. Muitos crimes, em redor de sua história. E, apesar disso, tão amoroso e tão amado por aquela Muntaz Mahal, a "Coroa do Palácio", que lhe deu tantos filhos, e, ao dar-lhe o último, morreu. (Meireles, I999, 246) 
Viagem à Índia: Cecília Meireles e Octavio Paz

LUÍS ANTÔNIO CONTATORI ROMANO

Vejamos, como em linguagem mais informativa, prosaica e menos idealizadora, Paz (I996, 50-5I) trata da ascensão de Xá Jahan ao trono:

Sucedeu a Jahangir seu filho, Xá Jahan, que assumiu o poder depois de assassinar, segundo a tradição da dinastia, seu irmão e outros parentes suspeitos de aspirar ao trono.

O Xá Jahan é famoso, com justiça, pelas obras de arquitetura que deixou em Agra, Déli e outros lugares.

Enquanto Paz dá nome aos criminosos e aos assassinados, embora considerando que todos eles se insiram em uma mesma tradição de ardis para ascender ao trono, Cecília parte da generalização, faz apenas referência à tradição sanguinária da dinastia mongol na Índia. A própria generalização, embora em gradação, é construída a partir de eufemismos: os príncipes são inquietos, ciumentos e ambiciosos, o que culmina no "sangue derramado". Enquanto Paz emprega diretamente o nome da ação: “assassinar”, assim como dá nome a assassinos e assassinados. Em Cecília, a generalização inicial funciona como um eufemismo para aliviar a figura de Xá Jahan dos crimes cometidos visando ascender ao trono, já que ele apenas se insere na tradição dessa prática. Na sequência, os “crimes ao redor de sua história” são completamente empalidecidos diante de seu retrato, em que uma auréola é sugerida a encobri-lo, como nos santos católicos, ou ainda diante da lembrança de seu amor por Muntaz Mahal. Relevamos, ao ler esse relato, os crimes cometidos para alcançar o poder, como também não nos perguntamos sobre a memória das outras esposas, não reveladas por essa "história oficial" dos guias de turismo.

A visita ao Taj Mahal, em Agra, se dá ao anoitecer e a sensação é de que o mármore branco da construção e o céu se espelham e se envolvem. A fruição da beleza artística parece sugerir a entrada no mundo transcendente platônico, 
o narrador-lírico parece se converter em só espírito. Vejamos mais um fragmento da crônica de Cecília:

Tão denso é o luar que tudo se torna impalpável: chão, ciprestes, muros, os vultos humanos, e seus movimentos e gestos. O luar atravessa tudo: se falarmos, a voz é absorvida por esta claridade esponjosa, ensurdecente, em que tudo se converte com delícia. Terá ficado no pórtico o nosso corpo, como um trajo miserável, num vestíbulo? Isto que somos agora é já outra coisa - aérea e resvalante: um pouco de vento que ainda pensa e recorda, apenas. (Meireles, I999, 247-248)

Impressão de que apenas a alma penetra por esse portal, o corpo é deixado afora. Portal que dá entrada a um cenário de plena claridade, em que a alma se transforma em vento, cuja voz é absorvida pela luz, que parece penetrar no mármore esponjoso do monumento, símbolo do que se eterniza e da unidade do Ser que tudo absorve. Haverá imagem mais bela para transformar a visita a um monumento humano, o Taj Mahal, em porta de entrada para a Beleza etérea? Beleza cujo ser esponjoso agrega a própria alma do visitante em êxtase sinestésico. Por contraste, poderíamos pensar em uma comparação desse monumento mortuário, cuja brancura fluida tudo absorve, com o também belo Monumento aos Mortos, erguido em I899 pelo escultor Paul-Albert Bartholomme, que adorna o Cemitério Père Lachaise, em Paris. Diferentemente da visão hindu, para quem a noção de tempo e de espiritualidade envolve uma integração, ao final da lei cármica, da consciência individual na unidade do Ser, como observamos a partir de Paz (I996), a visão cristã parece envolver a entrada para o mistério, o imponderável e indevassável da vontade divina absoluta, metaforizada pelo portal escuro, diante do qual os mortos, nus, devem aceder em súplica. O imponderável se faz representar também pelas diferentes idades 
Viagem à Índia: Cecília Meireles e Octavio Paz

LuÍS ANTÔNIO CONTATORI ROMANO

dos mortos, marca que enfatiza a efemeridade e a fragilidade da vida, tal como representado por Bartholomme.

O Taj Mahal, como símbolo do amor de Xá Jahan pela esposa morta, é antevisto no belíssimo texto "Taj Mahal: forma do amor...", de Episódio Humano (Meireles, 2007), edição póstuma de uma série de crônicas que a própria autora deixara preparada em forma de livro, as quais foram publicadas entre I929 e I930 no periódico carioca O Jornal. Trata-se, portanto, de texto que testemunha a admiração de juventude de Cecília Meireles pela Índia, seus monumentos e sua história, pois precede em mais de vinte anos a viagem que realizou ao país em I953, quando, de fato, visitou a cidade de Agra.

Nessa crônica, o Taj Mahal aparece como sublimação do amor de Xá Jahan, ao perder Muntaz Mahal, símbolo desse amor e da perda dele, e também da própria efemeridade das ações e dos sentimentos humanos. Chama a atenção no texto a descrição pormenorizada do monumento e, principalmente, da claridade que o envolve e que sua matéria esponjosa parece absorver, imagem que reaparecerá em “Vimos o Taj Mahal”, escrita depois da visita ao monumento. No texto de juventude há uma referência quase explícita à Teoria platônica das Reminiscências, a que a cronista associa o monumento. Vejamos:

O Taj Mahal não vive só por si. Tem uma serenidade, um equilíbrio, uma completação que o fazem participar da natureza sensível e incorpórea das idéias.

A abundância da terra e o labor obstinado dos homens construíram-lhe essa atitude branca, estacionando entre todos os quadrantes, mergulhando no céu, confundindo com os luares, mergulhando no próprio solo, dentro de uma água recordativa como um olhar.

Mas essa atitude também tem de passar, como as coisas imperduráveis, quando chegar a velhice que há também para as coisas. 
CARACOL 3 / DOSSIÊ

E que fica, então, para sempre?

O mesmo que fica de nós: aquele sutil impulso, que nasce de si mesmo, e que, depois

de tudo, perdura como constante Causa. (Meireles, 2007, I58-I59)

Entretanto, nessa crônica, o platonismo ceciliano, de juventude, parece se mostrar menos conflituoso que em textos posteriores, ao reconhecer que embora a beleza do Taj Mahal o aproxime das Formas perfeitas e incorpóreas, ele é sim matéria, e está submetido ao tempo, à “velhice das coisas”. Restará dele apenas o "sutil impulso" que moveu sua construção, que também platonicamente poderíamos ler como a alma de seu criador que o teria espelhado nas formas absolutas de que guardava reminiscência. Como hoje sua imagem se reflete, fluida, no espelho d'água que o cerca, metáfora do olho humano que busca recordar e imitar a Ideia. Nesse sentido, a crônica “Taj Mahal, forma do amor...” parece, paradoxalmente, concretizar a própria Teoria das Reminiscências, à medida que o texto evoca uma forma não vista ainda pelos sentidos, mas lembrada pelo espírito - embora, de fato, refira-se a um monumento humano e não a uma Forma ideal. O texto de viagem imaginária traz os germens da motivação, na maturidade, para que a poeta realize a viagem real e ofereça, transfigurada, outra imagem poética do Taj Mahal. Ambas valem, não tanto pela referencialidade do monumento, então já banalizado em relatos turísticos, mas, sobretudo, pela singularidade do olhar da poeta-viajante que se plasma nessas crônicas em prosa-poética.

\section{REFERÊNCIAS BIBLIOGRÁfICAS}

Chevalier, Jean; Gheerbrant, Alain. Dicionário de Símbolos. 23.ed. Rio de Janeiro: José Olympio, 2009. 
Viagem à Índia: Cecília Meireles e Octavio Paz

LuÍS ANTÔNIO CONTATORI ROMANO

(Org.). O Olhar do Viajante - Dos Navegadores aos Exploradores. Coimbra: Almedina, 2003.

Damasceno, Darcy. Cecilia Meireles - O Mundo Contemplado. Rio de Janeiro: Orfeu, i967.

Luondo, Dilip. “Cecília Meireles e a Índia: viagem e meditação poética”. In: Gouvêa, Leila V.-B (Org.). Ensaios sobre Cecilia Meireles. São Paulo: HumanitasFapesp, 2007.

Machado, Álvaro Manue; PAGEAUX, Daniel-Henri. Da Literatura Comparada à Teoria Literária. Lisboa: Edições 70, I988.

Meireles, Cecília. Crônicas de Viagem, Vol. 2. Rio de Janeiro: Nova Fronteira, I999.

. Crônicas de Educação, Vol. 5. Rio de Janeiro: Nova Fronteira, 200ıа.

Poesia Completa - Edição do Centenário. Organização, apresentação e estabelecimento de texto por Antonio Carlos Secchin. Rio de Janeiro: Nova Fronteira, 200Ib.

Episódio Humano. Rio de Janeiro: Desiderata, 2007.

Onfray, Michel. Teoria da Viagem - Poética da Geografia. Porto Alegre: L\&PM, 2009 .

Paz, Octavio. O Arco e a Lira. 2.ed. Rio de Janeiro: Nova Fronteira, I982.

. Convergências. Rio de Janeiro; Rocco, I99I.

Vislumbres da Índia. São Paulo: Mandarim, I996.

Pinto-Correia, David. “Deslumbramento, horror e fantasia. O olhar mágico na literatura de viagens”. In: Cristóvão, Fernando (Org.). Condicionantes Culturais da Literatura de Viagens - Estudos e Bibliografias. Coimbra: Almedina, 2002.

Platão. Fédon. São Paulo: Abril Cultural, I972.

80 
CARACOL 3 / DOSSIÊ

Diálogos: Mênon - Banquete - Fedro. Tradução brasileira diretamente do grego pelo Dr. Jorge Paleikat. 4.ed. Porto Alegre: Globo, I960.

Valéry, Paul. Variedades. São Paulo: Iluminuras, 2007.

Yutang, Lin. A Importância de Viver. Io ed. Porto Alegre: Globo, I986. 